\title{
Experimental Hypocalcemia Induced by Hemodialysis in Goats
}

\author{
Norio YAMAGISHI*, Asako OISHI, Jun SATO, Reeko SATO and Yoshihisa NAITO** \\ Department of Veterinary Internal Medicine, Faculty of Agriculture, Iwate University, Morioka, Iwate 020-8550, Japan
}

(Received 16 March 1999/Accepted 28 July 1999)

ABSTRACT. To evaluate whether hemodialysis with a dialysate containing no calcium (Ca-free HD) can induce hypocalcemia and restore the clinical signs and blood biochemical changes in naturally occurred hypocalcemic disorder in ruminants, the clinical signs and the changes in plasma electrolytes and minerals concentrations were observed in goats during 6-hr hemodialysis. The four goats received hemodialysis with the dialysate containing calcium ( $\mathrm{Ca} \mathrm{HD}$ ), and 10 days later they had $\mathrm{Ca}$-free HD. The plasma ionized $\mathrm{Ca}$ (Ca ${ }^{++}$) and total $\mathrm{Ca}(\mathrm{TCa})$ concentrations were not affected by $\mathrm{Ca} \mathrm{HD}$, whereas the levels significantly decreased during whole period of Ca-free HD. The $\mathrm{Ca}^{++}$and TCa concentrations were $0.69 \pm 0.06 \mathrm{mmol} / l$ and $5.9 \pm 0.3 \mathrm{mg} / \mathrm{d} l$ at $6 \mathrm{hr}$ of Ca-free HD, respectively. The clinical signs observed during Ca-free HD seemed to resemble to those in naturally occurred hypocalcemic cases that were reported previously. Therefore, Ca-free HD was suggested to be one of the possible methods to induce experimental hypocalcemia in ruminants.-KEY wORDS: experimental hypocalcemia, goat, hemodialysis, ruminant.

J. Vet. Med. Sci. 61(12): 1271-1275, 1999

There are numerous reports dealing with an experimentally induced hypocalcemia in ruminants as a model for studies of the pathophysiology and prophylaxis of milk fever (parturient paresis, parturient hypocalcemia) $[3,8,9,12,13,18,19,22]$. Most of the reports have described an intravenous infusion of disodium ethylenediaminetetraacetic acid $\left(\mathrm{Na}_{2}\right.$ EDTA) solution to induce experimental hypocalcemia. Some of the authors have reported that accidental death sometimes occurs in the experimental animals as a result of the $\mathrm{Na}_{2}$ EDTA infusion $[8,22]$. The cause of death remains unclear, but they have assumed that death occurs due to the side effects of the $\mathrm{Na}_{2}$ EDTA infusion $[8,22]$. Nephrotoxicity and hepatoxicity are known to be side effects of the $\mathrm{Na}_{2}$ EDTA infusion [6, 7, $10]$.

Hemodialysis is one of safe therapeutic methods for human patients with severe renal failure. It has been reported that hemodialysis with a dialysate containing no calcium (Ca-free HD) can lower the plasma calcium concentration in dogs $[4,5,23]$. But less is known as to whether $\mathrm{Ca}$-free HD can restore the clinical signs and blood biochemical changes in naturally occurred hypocalcemic disorder in ruminants. We therefore examined the clinical signs and the changes in plasma electrolytes and minerals concentrations during 6-hr Ca-free HD in goats.

\section{MATERIALS AND METHODS}

Animals: Four clinically healthy crossbred goats (female, aged 2 to 4 years, and weighing 34 to $46 \mathrm{~kg}$ ) were penned

\footnotetext{
* Present address: Yamagishi, N., Department of Veterinary Surgery, Obihiro University of Agriculture and Veterinary Medicine, Obihiro, Hokkaido 080-8555, Japan.

** Correspondence to: Dr. Naito, Y., Department of Veterinary Internal Medicine, Faculty of Agriculture, Iwate University, Iwate 020-8550, Japan.
}

and accustomed to handling for at least 1 month. They were fed a commercial grain mixture and timothy hay ad libitum. Each goat had two catheters (Anthron Catheter II1470, Toray Medical Co., Ltd., Tokyo) inserted into the left carotid artery and jugular vein for hemodialysis and another one into the right jugular vein for collecting blood samples. The goats received 6 -hr hemodialysis with a dialysate containing calcium (Ca HD) 10 days after the catheterization. They received 6-hr Ca-free HD 10 days after Ca HD.

Dialysate: One hundred $l$ of dialysate was used in each hemodialysis. The contents of the electrolyte (in $\mathrm{mmol} / l$ ) in the dialysate for $\mathrm{CaHD}$ were $\mathrm{NaCl}$ (105), $\mathrm{KCl}$ (4), $\mathrm{MgCl} \cdot 6 \mathrm{H}_{2} \mathrm{O}$ (1), $\mathrm{CH}_{3} \mathrm{COONa} \cdot 3 \mathrm{H}_{2} \mathrm{O}$ (12), $\mathrm{NaHCO}_{3}$ (25), $\mathrm{C}_{6} \mathrm{H}_{12} \mathrm{O}_{6}$ (3.5) and $\mathrm{CaCl}_{2}$ (1.25). The dialysate for Ca-free $\mathrm{HD}$ contained the same electrolytic contents except for $\mathrm{CaCl}_{2}$. The $\mathrm{pH}$ of the dialysate was adjusted to 7.3 with 10 $\mathrm{N} \mathrm{HCl}$ and the osmolality was about $280 \mathrm{mOsm} / \mathrm{kg}$.

Hemodialysis: A dialyzer (Mera Crystal S.SP 0.8, Senko Medical Instrument Mfg, Co., Ltd., Tokyo), filled with heparinized sterile saline, was connected to a dialysate inflow-outflow equalizer (Dialife S-11, Senko Medical Instrument Mfg., Co., Ltd., Tokyo) and a blood pump (Dialife S-7, Senko Medical Instrument Mfg, Co., Ltd., Tokyo). Before $10 \mathrm{~min}$ of hemodialysis, the goats received an intravenous administration of heparin sodium (300 IU/ $\mathrm{kg}$ ). The flow of dialysate was maintained at $500 \mathrm{ml} / \mathrm{min}$ at $38^{\circ} \mathrm{C}$. The blood flow was regulated to $3 \mathrm{~m} / / \mathrm{kg} / \mathrm{min}$ with no pressure gradient across the membrane. Each of the goats stood in a small wooden crate during the hemodialysis.

Clinical observation and blood biochemistry: Clinical observation and blood sampling were done immediately before ( $0 \mathrm{hr}$ ) and at $1 \mathrm{hr}$ intervals during hemodialysis ( 1 to $6 \mathrm{hr}$ ). The rectal temperature, heart rate and respiration rate were recorded. The clinical signs observed during hemodialysis were mobility, demeanor, shivering, ruminal motility and heart sound quality by auscultation. Blood 


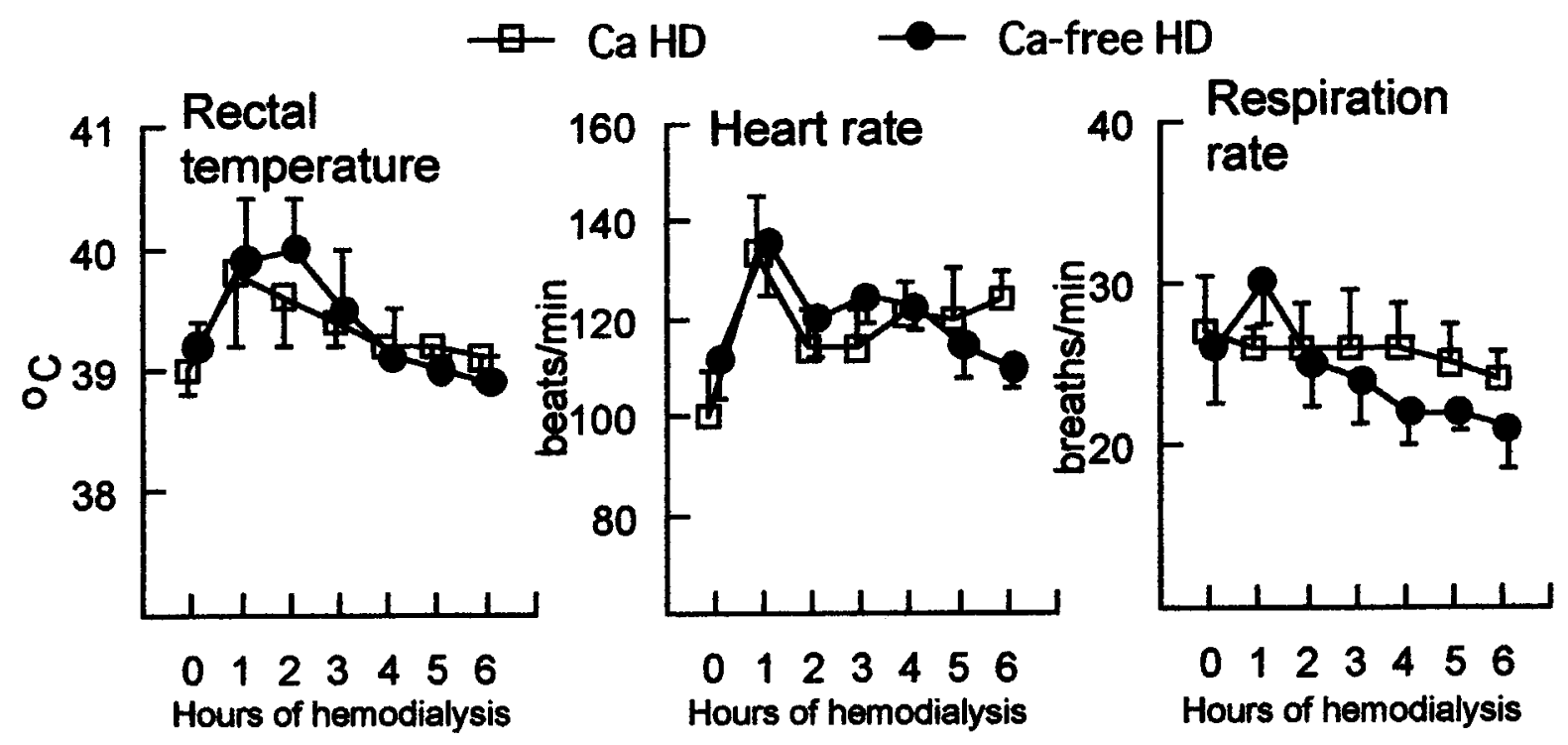

Fig. 1. Changes in rectal temperature, heart rate and respiration rate during $\mathrm{Ca} \mathrm{HD}$ and $\mathrm{Ca}$-free HD.

was taken in a $2.5-\mathrm{m} l$ heparinized syringe. The plasma concentrations of ionized calcium $\left(\mathrm{Ca}^{++}\right)$, sodium $\left(\mathrm{Na}^{+}\right)$, potassium $\left(\mathrm{K}^{+}\right)$and bicarbonate $\left(\mathrm{HCO}_{3}{ }^{-}\right)$were determined by means of the 288 Blood Gas System (Ciba Corning Diagnostics Corp., CA, U.S.A.), and the plasma ionized chloride $\left(\mathrm{Cl}^{-}\right)$by C-80A (Jookoo Co., Ltd., Tokyo). The plasma total calcium (TCa) and magnesium $(\mathrm{Mg})$ concentrations were determined by atomic absorption spectrophotometry [20], and inorganic phosphorus (P) by colorimetry [2].

Statistical analysis: The rectal temperature, heart rate, respiration rate and blood biochemical data were expressed as means \pm standard error. One-way analysis of variance was used to observe the effect of each $\mathrm{Ca}$-free $\mathrm{HD}$ and $\mathrm{Ca}$ HD. If the effects were significant, the values at 1 to $6 \mathrm{hr}$ during each hemodialysis were compared with those at $0 \mathrm{hr}$ by Turkey multiple comparison test. The significance was taken at $P<0.05$.

\section{RESULTS}

Clinical findings: The rectal temperature and heart rate tended to reach the maximum at $1 \mathrm{hr}$ of hemodialysis, but these changes had no statistical significance in $\mathrm{Ca} \mathrm{HD}$ and Ca-free HD (Fig. 1). The respiration rate was not affected by either $\mathrm{Ca} \mathrm{HD}$ or Ca-free HD. In $\mathrm{Ca} \mathrm{HD}$, one of the goats temporally staggered and shivered at $1 \mathrm{hr}$ of hemodialysis. The other goats with $\mathrm{Ca}$ HD did not show any abnormal signs. During the entire period of $\mathrm{Ca}$-free HD, three goats became ataxic and there was repeated reeling and falling associated with muscle tremor. All of the goats showed signs of dullness, shivering, ruminal stasis and decreased heart sound intensity as detected by auscultation during Ca-free HD.

Blood biochemical results: There were statistically

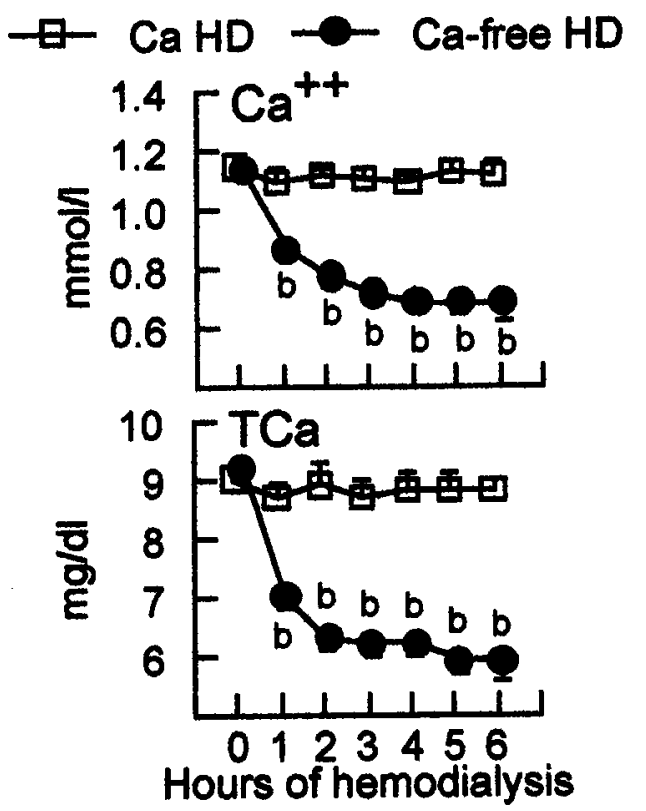

Fig. 2. Changes in plasma $\mathrm{Ca}^{++}$and $\mathrm{TCa}$ concentrations during $\mathrm{Ca} \mathrm{HD}$ and $\mathrm{Ca}$-free $\mathrm{HD}$. Significant difference from value at $0 \mathrm{hr}$ in $\mathrm{Ca}$-free HD, b: $P<0.01$.

significant changes in the plasma $\mathrm{Ca}^{++}, \mathrm{TCa}, \mathrm{P}, \mathrm{Mg}$ and $\mathrm{HCO}_{3}{ }^{-}$concentrations during $\mathrm{Ca} \mathrm{HD}$ and/or Ca-free HD (Figs. 2 and 3). Ca HD had no effect on changes in the plasma $\mathrm{Ca}^{++}$and TCa concentrations, but $\mathrm{Ca}$-free HD induced a significant reduction at 1 to $6 \mathrm{hr}$. The plasma $\mathrm{Ca}^{++}(1.13 \pm 0.03 \mathrm{mmol} / \mathrm{l})$ and TCa levels $(9.2 \pm 0.4 \mathrm{mg} / \mathrm{d} l)$ at $0 \mathrm{hr}$ decreased to $0.69 \pm 0.06 \mathrm{mmol} / l$ and $5.9 \pm 0.3 \mathrm{mg} / \mathrm{d} l$ at $6 \mathrm{hr}$ of Ca-free HD, respectively $(p<0.01)$. The plasma $\mathrm{P}$ 


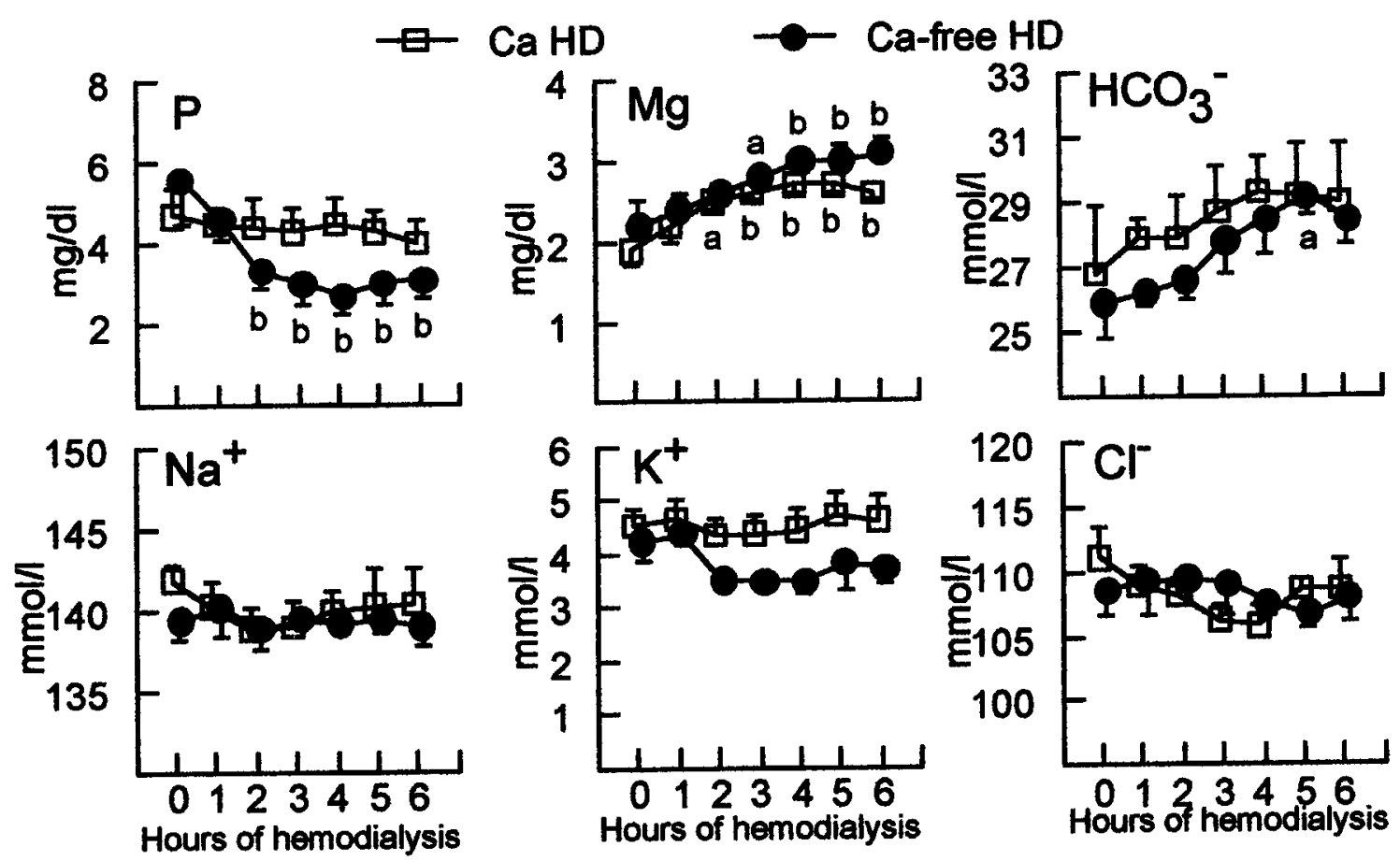

Fig. 3. Changes in plasma $\mathrm{P}, \mathrm{Mg}, \mathrm{HCO}_{3}{ }^{-}, \mathrm{Na}^{+}, \mathrm{K}^{+}$and $\mathrm{Cl}^{-}$concentrations during $\mathrm{Ca} \mathrm{HD}$ and $\mathrm{Ca}$-free $\mathrm{HD}$. Significant difference from value at $0 \mathrm{hr}$ in $\mathrm{Ca} \mathrm{HD}$ or Ca-free $\mathrm{HD}$, a: $P<0.05$, b: $P<0.01$.

concentrations were not affected by $\mathrm{Ca} \mathrm{HD}$, but the levels $(5.6 \pm 1.1 \mathrm{mg} / \mathrm{d} l$ at $0 \mathrm{hr})$ were low at $4 \mathrm{hr}(2.7 \pm 0.5 \mathrm{mg} / \mathrm{d} l)$ during Ca-free $\mathrm{HD}(P<0.01)$. The plasma $\mathrm{Mg}$ concentrations at $0 \mathrm{hr}$ were $1.9 \pm 0.2 \mathrm{mg} / \mathrm{d} l$ in $\mathrm{Ca} \mathrm{HD}$ and $2.2 \pm 0.3 \mathrm{mg} / \mathrm{d} l$ in Ca-free HD. These values were significantly high during 2 to $6 \mathrm{hr}$ of $\mathrm{Ca} \mathrm{HD}(2.6 \pm 0.1 \mathrm{mg} / \mathrm{d} l$ at $6 \mathrm{hr}, p<0.01)$ and during 4 to $6 \mathrm{hr}$ of Ca-free $\mathrm{HD}(3.1 \pm 0.2 \mathrm{mg} / \mathrm{d} l$ at $6 \mathrm{hr}$, $p<0.01)$. The plasma $\mathrm{HCO}_{3}{ }^{-}$levels during $\mathrm{Ca}$-free $\mathrm{HD}$ were higher at $5 \mathrm{hr}(29.2 \pm 1.3 \mathrm{mmol} / l ; p<0.05)$ than those at $0 \mathrm{hr}(25.9 \pm 2.3 \mathrm{mmol} / l)$. The plasma $\mathrm{Na}^{+}, \mathrm{K}^{+}$, and $\mathrm{Cl}^{-}$ concentrations were not affected by $\mathrm{Ca}$-free HD or $\mathrm{Ca} \mathrm{HD}$.

\section{DISCUSSION}

Clinical signs of hypocalcemia in goats generally resemble those in cows [21]. The affected goat shows signs of ataxia, shivering and muscle tremor, followed by recumbency. Experimental studies on goats made hypocalcemic by intravenous infusion of $4 \% \mathrm{Na}_{2}$ EDTA solution $[12,13]$ described how staggering and restlessness occurred in a mild hypocalcemic state (more than a $6 \mathrm{mg} / \mathrm{d} l$ Ca concentration in blood). The goats had depressed anal and palpebral reflex and repeated reeling and falling with moderate hypocalcemia ( 4 to $5 \mathrm{mg} / \mathrm{d} l$ ), and exhibited complete recumbency in a severe hypocalcemic state (less than $2 \mathrm{mg} / \mathrm{d} l)[12,13]$. In the present study, the goats showed signs of marked hypocalcemia during Ca-free HD. The plasma $\mathrm{Ca}^{++}$and TCa concentrations were around 0.69 $\mathrm{mmol} / l$ and $5.9 \mathrm{mg} / \mathrm{d} l$ during Ca-free HD, which were similar levels to a mild to moderate hypocalcemic state in previous experimental studies on hypocalcemic goats [12, 13]. The clinical signs found in the goats on Ca-free HD were ataxia (i. e., staggering and repeated reeling and falling, associated with muscle tremor), dullness, shivering, ruminal stasis and decreased heart sound intensity. These clinical signs seemed to resemble those in milk fever cows and experimental hypocalcemic ruminants previously reported $[8,12,13,17,18,21,22]$.

Although Ca HD did not affect the plasma $\mathrm{Ca}^{++}$and TCa concentrations, only one goat temporally staggered and shivered during the early period of Ca HD. The rectal temperature and heart rate showed a tendency to increase during both $\mathrm{Ca} \mathrm{HD}$ and $\mathrm{Ca}$-free HD. In human medicine, it has been noted that headache, chest and back pain, mental confusion, muscle twitching, dyspnea and diaphoresis often occur during hemodialysis [14, 25]. It has been reported that these symptoms occur in human patients during hemodialysis as a result of complications that may arise following the interaction between blood and the dialyzer [25]. It has been considered that possible factors contributing to this interaction are the excessive removing of body water, the rapid shift in the acid-base status, and the participation of cytokines and endotoxins $[11,16]$. In the present study, it was supposed that the temporal clinical signs during $\mathrm{Ca} \mathrm{HD}$ and the tendency to a high rectal temperature and heart rate during both $\mathrm{Ca} \mathrm{HD}$ and $\mathrm{Ca}$-free HD occurred as complications similar to those in human patients on hemodialysis.

It is well known that hypophosphatemia occurs in cows with milk fever $[17,21]$. This may be caused by phosphorus 
loss in colostrum, inadequate phosphorus intake around parturition, inadequate phosphorus mobilization from bone, and/or phosphorus diuresis caused by the high blood concentrations of parathyroid hormone $(\mathrm{PTH})$ due to hypocalcemia [17]. In the present study, the plasma $\mathrm{P}$ concentrations significantly decreased followed by a reduction in the $\mathrm{Ca}$ concentrations during $\mathrm{Ca}$-free $\mathrm{HD}$, which was the same result as in previous studies on experimental hypocalcemia induced by $\mathrm{Na}_{2}$ EDTA infusion in cows and sheep $[3,9,18,19,22]$. In experimental hypocalcemia, it is suggested that the hypophosphatemia is due to PTH action. The secretion of PTH is stimulated by falling plasma $\mathrm{Ca}^{++}$ levels. The high blood concentrations of PTH lower the plasma $\mathrm{P}$ concentrations by increasing renal phosphate excretion and by increasing the salivary phosphate secretion $[3,15]$.

In the present study, the plasma $\mathrm{Mg}$ concentrations increased during both of $\mathrm{Ca} \mathrm{HD}$ and $\mathrm{Ca}$-free HD. There was concern that this $\mathrm{Mg}$ elevation resulted from a relatively high $\mathrm{Mg}$ concentration in the dialysate; so it was necessary to reduce the $\mathrm{Mg}$ concentration in the dialysate in this experiment.

The present study describes how the plasma $\mathrm{HCO}_{3}{ }^{-}$ concentrations increased temporally at $5 \mathrm{hr}$ of Ca-free HD. Recently, Barzanji and Daniel [1] and Setia and his associates [24] have reported that a rise occurs in the plasma $\mathrm{HCO}_{3}{ }^{-}$concentrations as well as in arterial and venous blood pH, carbon dioxide pressure and base excess in experimental hypocalcemic cows and sheep induced by the $\mathrm{Na}_{2}$ EDTA infusion. It is suggested that these changes were due to an impairment of oxygen uptake by the pulmonary blood flow and an impairment of peripheral tissue uptake of oxygen during hypocalcemia [1, 24].

In conclusion, the present study suggested that $\mathrm{Ca}$-free HD was one of the possible experimental methods to induce hypocalcemia and to restore the clinical signs and blood biochemical changes in naturally occurring hypocalcemic disorder in ruminants. But some unfavorable clinical signs sometimes occurred in the animals probably due to the complications that may arise following the interaction between blood and the dialyzer during hemodialysis.

ACKNOWLEDGMENTS. We thank Senko Medical Instrument Mfg. Co., Ltd. and Manbuirika Co., Ltd. for the cooperation.

\section{REFERENCES}

1. Barzanji, A. A. H. and Daniel, R. C. W. 1988. The effects of hypocalcaemia on blood gas and acid-base parameters in ruminants. Br. Vet. J. 144: 93-97.

2. Chen, P. S., Jr., Toribara, T. Y. and Warner, H. W. 1956. Microdetermination of phosphorus. Anal. Chem. 28: 17561766.

3. Daniel, R. C. W. and Moodie, E. W. 1979. Induced hypocalcaemia in cows and sheep. I. Changes in plasma inorganic phosphorus levels. Br. Vet. J. 135: 440-451.

4. Darsinos, J., Karli, J., Pestevos, A., Levis, G. and
Moulopoulos, S. 1988. Hemodialysis with calcium-free dialysate prevents myocardial creatine kinase depletion after brief coronary artery occlusion in dogs. Angiology 39: 865887.

5. Darsinos, J. T., Karli, J. N., Stathaki, S. N., Ziroyanins, P. N., Pistevos, A. C., Levis, M. and Moulopoulos, S. D. 1984. Effect of hypocalcemia on isoproterenol induced cardiotoxicity in dogs. Angiology 35: 152-162.

6. Doolan, P. D., Schwartz, S. L., Hayes, J. R., Mullen, J. C. and Cummings, N. B. 1967. An evaluation of the nephrotoxicity of ethylenediaminetetraacetate and diethylenetriaminepentaacetate in the rat. Toxicol. Appl. Pharmacol. 10: 481-500.

7. Dudley, H. R., Ritcie, A. C., Schilling, A. and Baker, W. H. 1955. Pathologic changes associated with the use of sodium ethylene diamine tetra-acetate in the treatment of hypercalcemia. New Engl. J. Med. 252: 331-337.

8. Fenwick, D. C. and Daniel, R. C. W. 1990. A comparison between the main clinical signs of milk fever in cows with those of hypocalcemia induced by $\mathrm{Na}_{2}$ EDTA solution. $\mathrm{J}$. Vet . Med. A37: 721-728.

9. Fenwick, D. C. and Daniel, R. C. W. 1992. Investigation of same pathophysiological effects of prolonged hypocalcaemia in sheep induced by infusing $\mathrm{Na}_{2}$ EDTA solution for 4 hours daily on three consecutive days. Br. Vet. J. 148: 301-313.

10. Fukuda, S., Hseih, Y. Y. and Chen, W. 1990. Toxicological study of DTPA as a drug (V): Toxicities of Ca-DTPA, CaEDTA and CBMIDA after intravenous injection in beagle dogs. Hoken Butsuri 25: 115-119.

11. Henderson, L. W., Koch, K. M., Dinarello, C. A. and Shaldon, S. 1983. Hemodialysis hypotension: The interleukin hypothesis. Blood Purification 1: 3-8.

12. Kan, J. B. 1979. Studies on calcium movement, electromyogram and electrocardiogram of experimental hypocalcemia in goats. Ph.D. Thesis. The University of Tokyo (in Japanese).

13. Kan, J. B. and Motoyoshi, S. 1979. Studies on experimental hypocalcemia in goats. J. Jpn. Vet. Med. Assoc. 32: 685-689 (in Japanese with English abstract).

14. Kennedy, A. C., Linton, A. L. and Eaton, J. C. 1962. Urea levels in cerebrospinal fluid after hemodialysis. Lancet 1 : 410-411.

15. Mayer, G. P., Marshak, R. R. and Kronfeld, D. S. 1969. Parathyroid effects on renal phosphorus excretion in the cow. Am. J. Physiol. 211: 1366-1370.

16. Mege, J. L., Sanguedolce, M. V., Purgus, R., Moulin, B., Bongrand, P., Capo, C. and Olmer, M. 1992. Chronic and intradialytic effects of high-flux hemodialysis on tumor necrosis factor- $\alpha$ production: Relationship to endotoxins. Am. J. Kid. Dis. 10: 482-488.

17. Oetzel, G. R. 1988. Parturient paresis and hypocalcemia in ruminant livestock. Vet. Clin. North Am. Food Anim. Pract. 4: 351-364.

18. Payne, J. M. 1964. The responses of cows to experimentally induced hypocalcaemia. II. Chronic experimental hypocalcaemia. Vet. Rec. 76: 77-81.

19. Payne, J. M., Sansom, B. F. and Manston, R. 1963. The response of cows to experimentally induced hypocalcaemia. I. Acute experimental hypocalcaemia. Vet. Rec. 75: 588-592.

20. Pybus, J. 1969. Determination of calcium and magnesium in serum and urine by atomic absorption spectrophotometry. Clin. Chem. Acta 23: 309-317.

21. Radostits, O. M., Blood, D. C. and Gay, C. C. 1994. Metabolic disease: parturient paresis (milk fever). pp. 1314-1328. 
In: Veterinary Medicine, 8th ed., Bailliere Tindall, London.

22. Ramberg, C. F., Jr., Mayer, G, P., Kronfeld, D. S., Aurbach G. D., Sherwood, L. M. and Potts, J. T. Jr. 1967. Plasma calcium and parathyroid hormone responses to EDTA infusion in the cow. Am. J. Physiol. 213: 878-882.

23. Samouilidou, E. C., Levis, G. E., Darsinos, J. T., Pistevos, A. C., Karli, J. N. and Tsiganos, C. P. 1991. Effect of low calcium on high-energy phosphates and sarcolemmal $\mathrm{Na}^{+} /$ $\mathrm{K}^{+}$-ATPase in the infarcted-reperfused heart. Biochem.
Biophysic. Acta 1070: 343-348.

24. Setia, M. S., Singh, A., Kahlon, R. S. and Randhawa, S. S. 1996. Alteration in the systemic acid-base status and blood gas dynamics during progressive hypocalcaemia in cows calves. Ind. J. Exp. Biol. 34: 375-376.

25. Walker, J. F., Lindsay, R. M., Sibbald, W. J. and Linton, A. L. 1984. Blood-dialyzer interactions: Hemodynamic manifestations in an animal model. Artif. Organs 8: 329-333. 